UDC 624.011.7

\title{
DESIGN OF COMPOSITE SKIN PANEL FOR ROOF IN ACCORDANCE WITH THE REQUIREMENTS OF EN 1995-1-1 AND GSN B.1.2-2:2006
}

\author{
Pichugin Sergiy $^{1 *}$, Shkirenko Sergiy ${ }^{2}$, Pents Maryna ${ }^{3}$ \\ ${ }^{1}$ Poltava National Technical Yuri Kondratyuk University https://orcid.org/0000-0001-8505-2130 \\ ${ }^{2}$ Poltava National Technical Yuri Kondratyuk University https://orcid.org/0000-0001-7149-3197 \\ ${ }^{3}$ Poltava National Technical Yuri Kondratyuk University https://orcid.org/0000-0001-8974-8557 \\ *Corresponding author E-mail: pichugin.sf@gmail.com
}

\begin{abstract}
In the article design of composite (timber and plywood) skin panel has been considered according European and national standards. The panel consists of timber webs and plywood skin. The design parameters are depth of webs and distance between webs within the defined skin parameters. In design the method of fictitious cross-section is applied. Check of the ultimate limit states is conducted in accordance with EN 1995-1-1 (ДБН В.2.6-161:2017). Loads to the panel are determined according to ДБН В.1.2.-2:2006. The usage of European and national standards complies with the actual requirements and widen methodological base.
\end{abstract}

Keywords: roof members; two-sided composite skin panel, design of building constructions, loads on building constructions

\section{ПРОЕКТУВАННЯ КЛЕСФАНЕРНОЇ ПАНЕЛІ ПОКРИТТЯ ВІДПОВІДНО ДО ВИМОГ ЕN 1995-1-1 і ДБН В.1.2-2:2006}

\author{
Пічугін С.Ф. ${ }^{\text {*, }}$ Шкіренко С.В. ${ }^{2}$, Пенц М.В. ${ }^{3}$ \\ ${ }^{1}$ Полтавський національний технічний університет імені Юрія Кондратюка \\ 2 Полтавський національний технічний університет імені Юрія Кондратюка \\ ${ }^{3}$ Полтавський національний технічний університет імені Юрія Кондратюка \\ *Адреса для листування E-mail: pichugin.sf@gmail.com
}

\begin{abstract}
Розглянуто проектування композитної панелі покриття згідно з європейськими і національними будівельними нормами. Панелі композитного типу (дерев'яні ребра й обшивка з фанери або OSB) часто застосовуються для покриття легкого типу. Для конструкцій, які мають у своєму складі матеріали з різними фізико-механічними властивостями, при проектуванні застосовується метод зведеного перерізу, що значно спрощує розрахунки. Оскільки обшивки панелі знаходяться в більш напруженому стані, ніж ребра, матеріал ребра (деревина) приводиться до матеріалу обшивок за допомогою коефіцієнта приведення. Він знаходиться як відношення модулів пружності матеріалів. Як приклад у статті наведено конструктивний розрахунок за першим граничним станом. Остання редакція національних норм щодо розрахунку дерев'яних конструкцій повністю базується на європейських будівельних стандартах. Із цих міркувань у статті розглянуто проектування конструкції відповідно до оригінального джерела. Натомість визначення характеристик міцності рекомендовано виконувати згідно з національними нормами, які одночасно виконують функції європейського стандарту EN 338. Навантаження на панель визначаються відповідно до норм, що $€$ не тільки традиційним в національній методології проектування будівельних конструкцій, але й, на думку авторів, більше відповідає критеріям надійності. Застосування в розрахунках одночасно національних і європейських проектних норм відповідає сучасним вимогам та розширює методологічну базу.
\end{abstract}

Ключові слова: клеєфанерна панель покриття, проектування будівельних конструкцій, навантаження на будівельні конструкції. 


\section{Introduction}

Nowadays new building codes adapted to European ones are used in Ukraine. There is a need to adapt the design methodology for the elements of timber structures.

Two-sided composite (timber and plywood or OSB) skin panel are most common. This type of panels is designed as a typical glued thin flanged internal I-beam with flanges on the top and bottom faces and subjected to a moment.

\section{Review of research sources and publications}

Design methods of composite skin panels for products in USA, Canada, and Europe are considered in publications $[1-4]$. As the flanges are thin, the stress in each flange due to bending is effectively an axial stress and the design value is taken to be the average value across the flange thickness. In calculating section properties for stressed-skin panels, the designer must consider the composite nature of the unit. Unless all materials in the panel have similar moduli of elasticity, some method must be employed to make allowance for the differences. Different moduli of elasticity may be reconciled by the «transformed section» use. The transformed-section approach is common to structural design of composite sections. It consists of «transforming» the actual section into one of equivalent strength and stiffness, but composed of a single material. Sections are generally transformed to the material of the panel most highly stressed portion.

The design requirements for the web are that it must be able to support the flexural stresses that arise, that the shear stress in the web must be acceptable, and that the glued joints between the web and the flanges must be able to transfer the horizontal shear stresses at the interface.

\section{Definition of unsolved aspects of the problem}

European design recommendations are based on the Eurocode load standards [5, 6]. Loads for building Ukrainian constructions can be used according rules of Ukrainian standard [7]. Dead loads determined rules of chapter 5 of [7]. Snow (variable) loads determined rules of chapter 8 of [7].

\section{Problem statement}

In the article the possibility of using the Ukrainian standards for loads on building constructions and European standards for design timber structure elements have been discussed.

\section{Basic material and results}

It is considered the composite skin panel design in accordance with the requirements [8]. Typical two-sided composite (timber and plywood) skin panel is used as a roof member for different types of roofing materials. Plywood is used for panel top and bottom skins and timber is used for panel webs.

For composite skin panel design it can be used rules of Ukrainian standard [9] which is based on rules [8]. In Ukraine characteristic values of strength classes according [9] should be used.
The effective flange width concept applies to flanges in compression and in tension, and unless a more detailed calculation is carried out, in accordance with the requirements of 9.1.2(3) [8]. The effective flange width, $b_{e f}$, as shown in Figure 1, for internal I-shaped sections, is as follows ([8] eq. (9.12)):

$$
b_{e f . c}=b_{c . e f}+b_{w} \text { and } b_{e f . t}=b_{t . e f}+b_{w} \text {. }
$$

Effective flange width of an I-beam section of the panel ([8], 9.1.2):

- in compression ([8], Table 9.1),

$$
b_{\text {c.ef }} \leq \min \left\{0,1 \cdot L ; 20 \cdot \delta_{t f}\right\} \text {; }
$$

- in tension ([8], Table 9.1),

$$
b_{t . e f} \leq 0,1 \cdot L \text { (only shear lag). }
$$

Designations accepted in the formulas:

$b_{c . e f}$ - design width of the flange in compression;

$b_{t . e f}$-design width of the flange in tension;

$b_{w}$ - design width of the web;

$L$ - span of panel;

$\delta_{t f}$ - top flange thickness;

$\delta_{b f}$ - bottom flange thickness.

The values $b_{c . e f}$ and $b_{t . e f}$ should not be greater than clear distance between webs $b_{f}$.

Panel has a cross-section of two different materials. It is convenient to go transformed section or fictitious section.

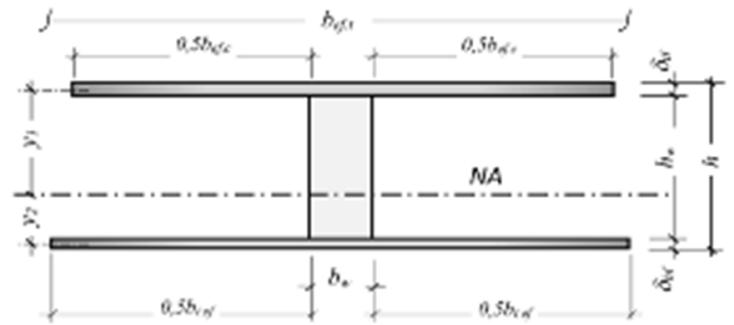

Figure 1 - Transform cross-section as I-beam

Coefficient for transformed section, as ratio of modulus

$$
n_{E}=E_{\text {o.mean }} / E_{\text {plw.0.mean }} .
$$

Transformed web thickness (into plywood)

$$
b_{w . t f d}=b_{w} \cdot n_{E} .
$$

Areas of cross-sections flanges:

- flange in compression

$$
A_{\text {eff.c. }}=b_{\text {ef.c }} \cdot \delta_{t f} ;
$$

- flange in tension

$$
A_{\text {ef.f.t }}=b_{\text {ef.t }} \cdot \delta_{b f} .
$$

Area of the webs

$$
A_{\text {ef. } w}=b_{w . t f d} \cdot h_{w} .
$$

Transformed area

$$
A_{\text {ef }}=A_{\text {ef.f.c }}+A_{\text {ef.f.t }}+A_{w} .
$$

First moment of area of the section about the top face:

$$
\begin{aligned}
A_{\text {lst }}= & A_{\text {ef.f.t }}\left(h-\delta_{b t} / 2\right)+A_{e f . w}\left(h_{w} / 2+\delta_{t f}\right)+ \\
& +A_{\text {eff.f. }} \delta_{t f} / 2 .
\end{aligned}
$$

Neutral axis $(N A)$ depth from the top face

$$
y_{t}=A_{1 s t} / A_{e f} \text {. }
$$


Second moment of area of the web about the $N A$

$$
I_{e f . w}=\frac{b_{w . t f d} \cdot h_{w}^{3}}{12}+A_{e f . w} \cdot\left(y_{t}-\left(\delta_{t f}+\frac{h_{w}}{2}\right)\right)^{2},
$$

Second moment of area of the top flange about the $N A$

$$
I_{e f . t f}=\frac{b_{e f . c} \cdot \delta_{t f}^{3}}{12}+A_{e f . f . c} \cdot\left(y_{t}-\frac{\delta_{t f}}{2}\right)^{2} .
$$

Second moment of area of the bottom flange about the $N A$

$$
I_{e f . b f}=\frac{b_{e f . t} \cdot \delta_{b f}^{3}}{12}+A_{e f . f . t} \cdot\left(h-y_{t}-\frac{\delta_{b f}}{2}\right)^{2}
$$

Instantaneous second moment of the transformed section area

$$
I_{e f}=I_{e f . w}+I_{e f . t f}+I_{e f . b f} .
$$

Stress in the flanges due to bending:

- bending stress (compression) in the top flange

$$
\sigma_{f . c . \max . d}=\frac{M_{d}}{I_{e f}} \cdot\left(y_{t}-\frac{\delta_{t f}}{2}\right) ;
$$

- bending stress (tension) in the bottom flange

$$
\sigma_{f . t . \max . d}=\frac{M_{d}}{I_{e f}} \cdot\left(h-y_{t}-\frac{\delta_{b f}}{2}\right) ;
$$

- bending stress check in the web

$$
\sigma_{w . c . d}=\frac{M_{d}}{I_{e f}} \cdot y_{l} \cdot n_{E}
$$

where $y_{l}=\max \left\{\left(y_{t}-\delta_{t f}\right) ;\left(h-\delta_{b f}-y_{t}\right)\right\}-$ maximum distance from the $N A$ to the extreme fibre.

Shear stress at the NA position:

$$
\tau_{v . d}=\frac{V_{d} \cdot S_{t f . N A}}{I_{e f} \cdot b_{w . t f d}} \cdot n_{E},
$$

where $S_{t f . N A}$ - first moment of area of the section above the $N A$

$$
S_{t f . N A}=b_{e f . c} \cdot \delta_{t f} \cdot\left(y_{t}-\frac{\delta_{t f}}{2}\right)+b_{w . t f d} \cdot \frac{\left(y_{t}-\delta_{t f}\right)^{2}}{2} .
$$

Shear stress of the glued joint between the web and the flanges:

- first moment of top flange area above the $N A$

$$
S_{t f}=b_{e f . c} \cdot \delta_{t f} \cdot\left(y_{t}-\frac{\delta_{t f}}{2}\right) ;
$$

- first moment of the bottom flange area about $N A$

$$
S_{b f}=b_{e f . t} \cdot \delta_{b f} \cdot\left(h-y_{t}-\frac{\delta_{b f}}{2}\right) ;
$$

Maximum value of first moment of area about $N A$

$$
S_{f}=\max \left\{S_{t f} ; S_{b f}\right) \text {; }
$$

Mean shear stress in the flange across the glue line

$$
\tau_{\text {mean.d }}=\frac{V_{d} \cdot S_{f}}{I_{e f} \cdot b_{w . t f d}} \cdot n_{E} .
$$

Design example of composite skin panel. Top skin of panel is plywood with thickness $\delta_{t f}=9 \mathrm{~mm}$, bottom skin of panel is plywood with thickness $\delta_{b f}=6 \mathrm{~m}$.

\begin{tabular}{|c|c|c|c|c|}
\hline Materials & 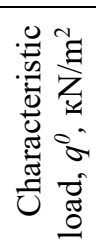 & 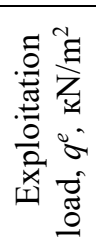 & 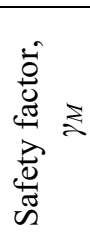 & 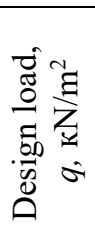 \\
\hline $\begin{array}{l}\text { 1. Profile Steel } \\
\text { Roofing Sheets }\end{array}$ & 0,15 & 0,15 & 1,3 & 0,195 \\
\hline 2. Plywood skin & 0,105 & 0,105 & 1,1 & 0,115 \\
\hline 3. Timber web & 0,078 & 0,078 & 1,1 & 0,086 \\
\hline $\begin{array}{l}\text { 4. Mineral wool } \\
\text { in panel }\end{array}$ & 0,060 & 0,060 & 1,2 & 0,072 \\
\hline $\begin{array}{l}\text { 5. PE steam } \\
\text { insulation }\end{array}$ & 0,005 & 0,005 & 1,1 & 0,006 \\
\hline $\begin{array}{l}\text { Total dead load } \\
\text { for panel }-q_{p}\end{array}$ & 0,398 & 0,398 & & 0,474 \\
\hline
\end{tabular}
Strength class of plywood F20/10 E40/20 with the faces aligned parallel to the direction of span [9]. The timber used for the web is class $C 22$ [9]. Panel is glued between the flanges and the web. Spanning between two supports $L=4,5 \mathrm{~m}$ apart. Nominal wide of panel $-1,5 \mathrm{~m}$. Construction sizes for panel are $448 \times 149 \mathrm{~cm}$. The structure functions in service class 2 conditions.

The design of panel complies with the rules in [8] at the ULS and [7] (loads).

Dead loads to the panel - weight of materials.

Table 1 - Dead load to the $1 \mathbf{~ m}^{2}$ panel

Variable loads to the panel - snow load may be set by National Norm [7]

Design snow load and exploitation snow load:

$S_{m}=\gamma_{f n} S_{0} C=1,04 \cdot 1450 \cdot 1=1508 \mathrm{~Pa}=1,508 \mathrm{kN} / \mathrm{m}^{2}$;

\begin{tabular}{|c|c|c|c|}
\hline Type of load & 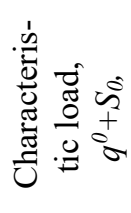 & 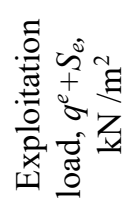 & 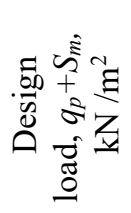 \\
\hline $\begin{array}{l}\text { 1. Dead load to the } \\
\text { panel }\end{array}$ & 0,398 & 0,398 & 0,474 \\
\hline $\begin{array}{l}\text { 2. Variable loads } \\
\text { to the panel (snow) }\end{array}$ & 1,450 & 0,710 & 1,508 \\
\hline $\begin{array}{l}\text { Total loads for } \\
\text { panel }-q_{\text {sum }}\end{array}$ & 1,848 & 1,108 & 1,982 \\
\hline
\end{tabular}

$S_{e}=\gamma_{f e} S_{0} C=0,49 \cdot 1450 \cdot 1=710,5 \mathrm{~Pa}=0,71 \mathrm{kN} / \mathrm{m}^{2}$, where $S_{0}=1450 \mathrm{~Pa}$ - characteristic snow load for Poltava ([7], Annex A).

Other values in these formulas are calculated according $([7]$.

Total loads to the panel

Loads for 1 meter of panel span

Total design loads for 1 meter of panel span (used table 2):

$q_{l}=q_{\text {sum }} \cdot B$,

where $B=1,5 m$ - wide of panel.

Table 2 - Total loads to the $1 \mathbf{~ m}^{2}$ panel

Exploitation load

$q^{e}=1,108 \cdot 1,5=1,662 \mathrm{kN} / \mathrm{m}$. 
Design load

$$
q_{l}=1,982 \cdot 1,5=2,973 \mathrm{kN} / \mathrm{m} \text {. }
$$

Actions. Design bending moment and design shear force

$$
\begin{aligned}
& M_{d}=q_{l} l^{2} / 8=2,973 \cdot 4,42^{2} / 8= \\
& =7,26 \mathrm{kN} \cdot \mathrm{m}=726 \mathrm{kN} \cdot \mathrm{cm} ; \\
& V_{d}=0,5 q_{l} l=0,5 \cdot 2,973 \cdot 4,42=6,57 \mathrm{kN},
\end{aligned}
$$

where $l=4,48-0,06=4,42 \mathrm{~m}-$ design span calculated with support effect.

Modification factor for permanent duration action ([8], eq .2.6):

$$
\begin{aligned}
& k_{\text {mod.perm }}=\left(k_{\text {mod.perm1 }} \cdot k_{\text {mod.perm2 }}\right)^{0,5}= \\
& =(0,6 \cdot 0,6)^{0,5}=0,6,
\end{aligned}
$$

where $k_{\text {mod.perm1 }}=0,6$ for solid timber (webs) and service class 2 ([8], Table 3.1);

$k_{\text {mod.perm } 2}=0,6$ for plywood (flanges) and service class 2 ([8], Table 3.1).

Factor for medium-duration action ([8], eq. 2.6):

$k_{\text {mod.medium }}=\left(k_{\text {mod.medium1 }} k_{\text {mod.medium2 }}\right)^{0,5}=$

$$
=(0,8 \cdot 0,8)^{0,5}=0,8 \text {, }
$$

where $k_{\text {mod.medium } 1}=0,8$ for solid timber (webs) and service class 2 ([8], Table 3.1);

$k_{\text {mod.medium2 }}=0,8$ for plywood (flanges) and service class 2 ([8], Table 3.1).

Load sharing factor, $k_{s y s}=1,0([8], 6.6)\left(k_{s y s}=1,1\right.$ can be used if it is required).

Depth factor for solid timber (webs) - is taken as $k_{h}=1$, as the depth is greater than $150 \mathrm{~mm}$ ([8], eq. (3.1)).

Geometric properties.

Structural dimensions of the panel are shown in the Fig. 2.

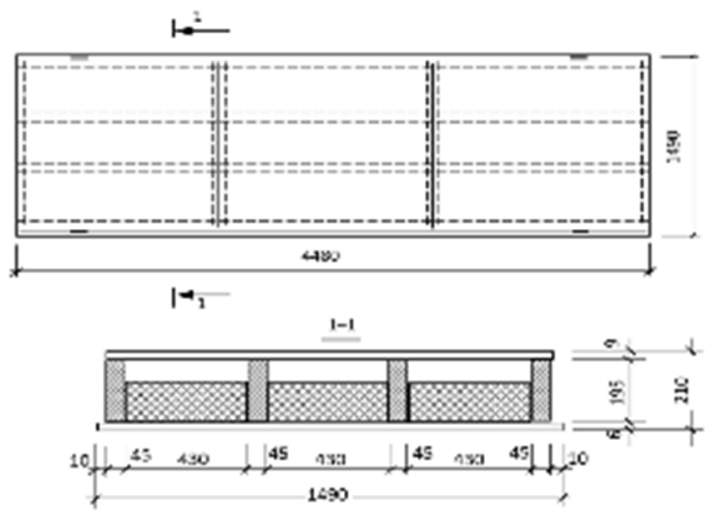

Figure 2 - Dimensions of panel

Clear distance between webs is $b_{f}=430 \mathrm{~mm}$. Top flange thickness is $\delta_{t f}=9 \mathrm{~mm}$. Bottom flange thickness is $\delta_{b f}=6 \mathrm{~mm}$. Dimensions of web are $b_{w} \times h_{w}$ $=45 \times 195 \mathrm{~mm}(50 \times 200 \mathrm{~mm}$ dimensions of sawn timber before planning according).

Depth parameters of cross-section

$$
h=h_{w}+\delta_{b f}+\delta_{t f}=19,5+0,6+0,9=21 \mathrm{~cm} .
$$

The effective flange width concept applies to flanges in compression and in tension, and unless a more detailed calculation is carried out, in accordance with the requirements of [8], 9.1.2(3). The effective flange width, $b_{e f}$, as it is shown in Figure 2, for internal I-shaped sections, is as follows:

$$
b_{e f . c}=b_{c . e f}+b_{w} \text { and } b_{e f . t}=b_{t . e f}+b_{w}([8], e q(9.12)) \text {. }
$$

Effective flange width of an I-beam section of the panel ([8], 9.1.2):

- in compression ([8], Table 9.1),

$$
b 1_{c . e f} \leq \min \left\{0,1 \cdot L ; 20 \cdot \delta_{t f}\right\} \leq 180 \mathrm{~mm}=18 \mathrm{~cm} \text {; }
$$

- in tension ([8], Table 9.1),

$$
b 1_{t . e f} \leq 0,1 \cdot L \leq 450 \mathrm{~mm}=45 \mathrm{~cm} \text { (only shear lag). }
$$

The values $b 1_{c . e f}$ and $b 1_{\text {t.ef }}$ should not be greater than value $b_{f}=430 \mathrm{~mm}$.

So, design sizes of the flanges are:

- in compression, $b_{c . e f}=b 1_{\text {c.ef }}=18 \mathrm{~cm}$;

- in tension, $b_{\text {t.ef }}=b_{f}=43 \mathrm{~cm}$.

Effective flange width:

- in compression, $b_{\text {ef.c }}=b_{\text {c.ef }}+b_{w}=18+4,5=22,5 \mathrm{~cm}$;

- in tension, $b_{\text {ef.t }}=b_{t . e f}+b_{w}=43+4,5=47,5 \mathrm{~cm}$.

Instantaneous - transformed section properties. As the panel has a cross-section of two different materials, it is convenient to go transformed section or fictitious section.

Coefficient for transformed section, as ratio of modulus according (1):

$$
n_{E}=E_{0 . \text { mean }} / E_{\text {plw.0.mean }}=10 / 4=2,5 \text {, }
$$

where $E_{0 \text {.mean }}=10 \mathrm{kN} / \mathrm{mm}^{2}-$ mean modulus of elasticity parallel for solid timber, strength classes $C 22$ ([9],

Table 5.1);

$E_{\text {plw. o.mean }}=4 \mathrm{kN} / \mathrm{mm}^{2}-$ modulus of elasticity parallel for plywood, strength classes F20/10 A40/20 (([9], Table Б.5).

Transformed web thickness (into plywood):

$b_{w . t f d}=b_{w} \cdot n_{E}=4,5 \cdot 2,5=11,25 \mathrm{~cm}$.

Areas of cross-sections flanges $(2,3)$

$A_{\text {ef.f.c }}=20,25 \mathrm{~cm}^{2}, A_{\text {eff.t. }}=28,5 \mathrm{~cm}^{2}$.

Area of the webs (4)

$A_{\text {ef. } w}=219,38 \mathrm{~cm}^{2}$.

Transformed area (5)

$A_{e f}=268,13 \mathrm{~cm}^{2}$.

First moment of section area about the top face (6)

$A_{\text {lst }}=2935,41 \mathrm{~cm}^{3}$.

Neutral axis $(N A)$ depth from the top face (7)

$y_{t}=10,9 \mathrm{~cm}$.

Second moment of web area about the $N A(8)$

$I_{\text {ef. } w}=6971 \mathrm{~cm}^{4}$.

Second moment of the top flange area about the $N A$ (9)

$I_{\text {ef.tf }}=2333 \mathrm{~cm}^{4}$.

Second moment of the bottom flange area about the $N A(10)$

$I_{\text {ef. } b f}=2758 \mathrm{~cm}^{4}$.

Instantaneous second moment of the transformed section area (11)

$I_{e f}=11962 \mathrm{~cm}^{4}$.

Bending stress check in the flanges and web (ULS). Stress in the flanges due to bending: 
- bending stress (compression) in the top flange (12): $\sigma_{\text {f.c.max.d }}=0,637 \mathrm{kN} / \mathrm{cm}^{2}=6,37 \mathrm{~N} / \mathrm{mm}^{2}$.

- bending stress (tension) in the bottom flange (13): $\sigma_{\text {f.t.max.d }}=0,592 \mathrm{kN} / \mathrm{cm}^{2}=5,92 \mathrm{~N} / \mathrm{mm}^{2}$

Strength of the top flange for plywood F20/10 E40/20 and $f_{\text {plw.c.k }}=15 \mathrm{~N} / \mathrm{mm}^{2}$ ([9], Table 5.5):

$$
\begin{gathered}
f_{\text {plw.c.d }}=f_{\text {plw.c.k }} \cdot k_{\text {mod.medium }} \cdot k_{\text {sys }}= \\
\quad=15 \cdot 0,8 \cdot 1=12 \mathrm{~N} / \mathrm{mm}^{2} .
\end{gathered}
$$

Strength of the bottom flange for plywood F20/10 E40/20 and $f_{\text {plw.t.k }}=9 \mathrm{~N} / \mathrm{mm}^{2}(([9]$, Table 5.5):

$$
\begin{aligned}
& f_{\text {plw.t. }}=f_{\text {plw.t.k }} \cdot k_{\text {mod.medium }} \cdot k_{\text {sys }}= \\
& \quad=9 \cdot 0,8 \cdot 1=7,2 \mathrm{~N} / \mathrm{mm}^{2} .
\end{aligned}
$$

Strength is satisfactory:

$$
\sigma_{\text {f.c.max.d }}<f_{\text {plw.c.d }}, \sigma_{\text {f.t.max.d }}<f_{\text {plw.t.d. }}
$$

Bending stress check in the web:

- maximum distance from the $N A$ to the extreme fibre,

$$
y_{l}=\max \left\{\left(y_{t}-\delta_{t}\right) ;\left(h-\delta_{b f}-y_{t}\right)\right\} \text {; }
$$$$
y_{1}=\max \{(10,9-0,9) ;(21-0,6-10,9\}=10 \mathrm{~cm} \text {; }
$$

- bending stress in the web (14),

$$
\sigma_{\text {w.c.d }}=1,525 \mathrm{kN} / \mathrm{cm}^{2}=15,25 \mathrm{~N} / \mathrm{mm}^{2} \text {. }
$$

Bending strength of the web for solid timber $C 22$ and $f_{\text {m.0.k }}=22 \mathrm{~N} / \mathrm{mm}^{2}(([9]$, Table 5.1):

$$
\begin{aligned}
f_{\text {m.0.d }} & =f_{\text {c.o. }} \cdot k_{\text {mod.medium }} \cdot k_{\text {sys }} \cdot k_{h}= \\
& =22 \cdot 0,8 \cdot 1 \cdot 1=17,6 \mathrm{~N} / \mathrm{mm}^{2} .
\end{aligned}
$$

Strength is satisfactory:

$$
\sigma_{\text {w.c.d }}<f_{\text {m.o.d }} \text {. }
$$

Shear stress of the web (ULS). First moment of the section area above the NA (16), $S_{t f \cdot N A}=780,48 \mathrm{~cm}^{4}$.

Shear stress at the NA position (15):

$$
\tau_{v \cdot d}=0,095 \mathrm{kN} / \mathrm{cm}^{2}=0,95 \mathrm{~N} / \mathrm{mm}^{2}
$$

Shear strength of the web material (solid timber $C 22$ ) with $f_{V . k}=2 \mathrm{~N} / \mathrm{mm}^{2}$ ([9], Table 5.1):

$$
f_{V . d}=f_{V . k} \cdot k_{\text {mod.medium }} \cdot k_{s y s}=2 \cdot 0,8 \cdot 1=1,6 \mathrm{~N} / \mathrm{mm}^{2} .
$$

Design shear strength is greater than the shear stress:

$$
\tau_{v . d}<f_{V . d}
$$

Shear stress of the glued joint between the web and the flanges (ULS).

First moment of top flange area above the NA (17):

$$
S_{t f}=212,58 \mathrm{~cm}^{4} \text {. }
$$

First moment of the bottom flange area about NA (18):

$$
S_{b f}=277,94 \mathrm{~cm}^{4} .
$$

Maximum value of first moment of area about NA:

$$
\begin{aligned}
& S_{f}=\max \left\{S_{t f} ; S_{b f}\right\}=\max \{212,58 ; 277,94\}= \\
& =277,94 \mathrm{~cm} .
\end{aligned}
$$

Mean shear stress in the flange across the glue line (19):

$$
\tau_{v . d}=0,034 \mathrm{kN} / \mathrm{cm}^{2}=0,34 \mathrm{~N} / \mathrm{mm}^{2}
$$

Rolling shear strength of the flange material (plywood F20/10 E40/20) with $f_{\text {plw.V.k }}=3,5 \mathrm{~N} / \mathrm{mm}^{2}$ (([9], Table Б.5):

$$
\begin{aligned}
& f_{p l w . V . d}=f_{\text {plw.V.k}} \cdot k_{\text {mod.medium }} \cdot k_{s y s}= \\
& =3,5 \cdot 0,8 \cdot 1=2,8 \mathrm{~N} / \mathrm{mm}^{2} .
\end{aligned}
$$

Rolling shear strength is determined according to ([8], 9.1.2(6):

- if $b_{w} \leq 8 \cdot \delta_{b f}$, then $f_{p l w . V . d}$;

- if $b_{w}>8 \cdot \delta_{b f}$, then $f_{p l w . V . d} \cdot\left(8 \cdot \delta_{b f} / b_{w}\right)$.

Design shear strength is greater than the shear stress:

$$
\tau_{v \cdot d}<f_{p l w . V . d}
$$

\section{Conclusion}

For design cross-section of composite panel, it can be applies a simple method of fictitious cross-section. The presented design methodology can be used to design composite (timber and plywood) skin panel in accordance with the requirements [8] and [9].

\section{References}

1. APA. (1990). Design and fabrication of plywood stressed-skin panels, Supplement 3, Form No. U813L. Tacoma, Washington, USA.

2. APA. (2014). Plywood design specification. design and fabrication of plywood stressed-skin panels, Supplement 312, Form No. U813M. Tacoma, Washington, USA.

3. Arons D.M. (2000). Properties and applications of double-skin building facades. Massachusetts Institute of Technology, Boston.

4. Porteous J. \& Kermani A. (2007). Structural timber design to Eurocode 5. Blackwell Science Ltd.

5. Eurocode 1 EN 1991-1-3: Actions on Structures - Part 13: General actions - Snow Loads. (2003). Brussels: CEN.

6. Eurocode 1: Actions on structures - Part 1-1: General actions - Densities, self-weight, imposed loads for buildings. (2001). Brussels: CEN.

7. ДБН В.1.2.-2:2006. (2006). Навантаження $і$ впливи. Київ: Мінрегіонбуд України.

8. EN 1995-1-1 (2004) Eurocode 5: Design of timber structures - Part 1-1: General - Common rules and rules for buildings [Authority: The European Union Per Regulation 305/2011, Directive 98/34/EC, Directive 2004/18/EC]

9. ДБН В.2.6-161:2017. (2017). Дерев'яні конструкиї. Київ: Мінрегіонбуд України
1. APA. (1990). Design and fabrication of plywood stressed-skin panels, Supplement 3, Form No. U813L. Tacoma, Washington, USA.

2. APA. (2014). Plywood design specification. design and fabrication of plywood stressed-skin panels, Supplement 312, Form No. U813M. Tacoma, Washington, USA.

3. Arons D.M. (2000). Properties and applications of double-skin building facades. Massachusetts Institute of Technology, Boston.

4. Porteous J. \& Kermani A. (2007). Structural timber design to Eurocode 5. Blackwell Science Ltd.

5. Eurocode 1 EN 1991-1-3: Actions on Structures - Part 13: General actions - Snow Loads. (2003). Brussels: CEN.

6. Eurocode 1: Actions on structures - Part 1-1: General actions - Densities, self-weight, imposed loads for buildings. (2001). Brussels: CEN.

7. DBN B.1.2-2.2006 (2006). Loads and loadings. Kyiv: Minregionbud of Ukraine.

8. EN 1995-1-1 (2004) Eurocode 5: Design of timber structures - Part 1-1: General - Common rules and rules for buildings [Authority: The European Union Per Regulation 305/2011, Directive 98/34/EC, Directive 2004/18/EC]

9. DBN B.2.6-161:2017. (2017). Wooden structures. Kiev: Minregionbud of Ukraine. 